\title{
Design Guide for Playgrounds
}

\author{
Gamze Şensoy and Mehmet İnceoğlu \\ Department of Architecture, Anadolu University, Eskisehir 26470, Turkey
}

\begin{abstract}
Children, who are the most weak people about sensibility and telling their desires clearly, act differently at every age phases. Because of this, child oriented designs must appeal to children about whole ages and features. Playgrounds are places where children of all ages and features spend their times commonly. But when these playgrounds were observed, that can be seen, playgrounds can not meet children's need and, because of this, they become quitted places. Within this article, child, play and playground concepts have been examined and the parameters of playground design have been classified. The aim of article is revealing the parameters for playgrounds design and offering a guide so that it can give an idea for the new designs.
\end{abstract}

Key words: Playground space, playground design parameters, spatial behaviour.

\section{Introduction}

Because of the rapid increase in urbanization and the destruction of green areas to built new settlements at the end of the 19th century, places where people can relax decreased. Although it is thought as "people" generally, who are affected from this situation, the most affected individuals are "children" in this group. With decreasing of green areas, children were limited with home and so far from social and physical activities. Several play equipments have located to unused fields, but these places have become dead and exposed to vandalism areas. Starting from here, it will be true to say that "the modernism gets the adult population, who are active about production relations to the center and ignores the rest of population's needs" [1].

Child, who is unable to express him/herself, is the most important individual of the world population [2], and children act differently at every age stage. Also behaviour types become different about growing style, the events that they witness, nutrition, environmental factors, shortly physical, biological and psychological causes for every children. Unfortunately, these differences aren't paid attention in design process.

Corresponding author: Gamze Şensoy, research assistant, research fields: architectural design, spatial quality and design philosophy. E-mail: gamze.snsy@gmail.com.
Designs are limited as "standard child", and the same play equipments are placed every fields like typical project. So, these areas lost its importance in time and become unqualified places. Adopting the place, wishing to be there are the proofs of design's quality, within this opinion, parameters for quality playground design have been suggested in this article and the steps of designing quality playgrounds have been revealed.

\section{Playground Design Parameters}

In today's conditions, the places, where children can spend time, have became insufficient, poor-graded and limited. Because of this, children became alienated from nature, their life has become unqualified and intensive urbanization has limited the acts of children and caused problems on their social developments [3]. Taking this into consideration, factors, that must be thought while quality playground is being designed, are as follows.

\subsection{Collaboration}

User-centered project designed by thinking of user's needs and environmental facts is related with quality design. Within the scope of this matter, design must be thought in every way and designers must corporate specialists who are knowledgeable with this 
case. "Although children are the most-effected people, they have no choice in the location or selection of play equipment. Important decisions are made by people who do not use the play area. Most often, decisions made about children's preferences are based on what someone believes would attract and please the child. One reason for this is that, it is difficult to get information from children. Another is that children are not usually allowed to represent their own interests [4]." There are many ways of involving users, especially children and adolescents, in the design process, so they may offer their creative design ideas. Methods include site safaris, design workshops using drawings and models and focus groups [5]. Besides, watching children at play is another good way to find out what they like to do [6].

\subsection{Location}

The location must be selected together with the community, including agreement with owners of the land/building and local government agencies [7]. Before the location was chosen, the area should be observed, and, especially, the case where children likes to be should be analysed. While this analysis is being done, central location, vehicle density, noise and air polution should be taken into consideration.

\subsection{Security}

Today, safety, security and liability have become major factors in determining the quality of children's outdoor play environments and play programs. While the safety and security of our children, whether in supervised or unsupervised play environments, justifiably deserves careful attention, the goals of safety and security must be balanced with the goal of providing stimulating and challenging environments for children's play and development. The concept of a healty and safe environment needs not to be at odds with child development objectives [8]. Children can not think about the event that would harm them or not. Because they do not have the ability to establish the

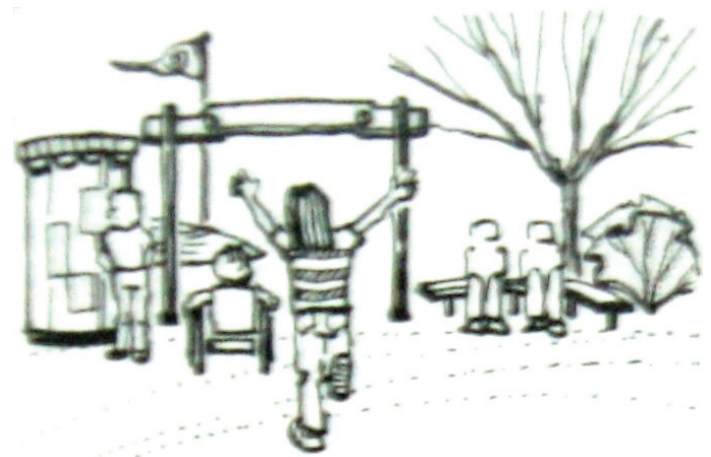

Fig. 1 Defined enterances for wellcoming playground areas according to Ref. $[8]{ }^{1}$

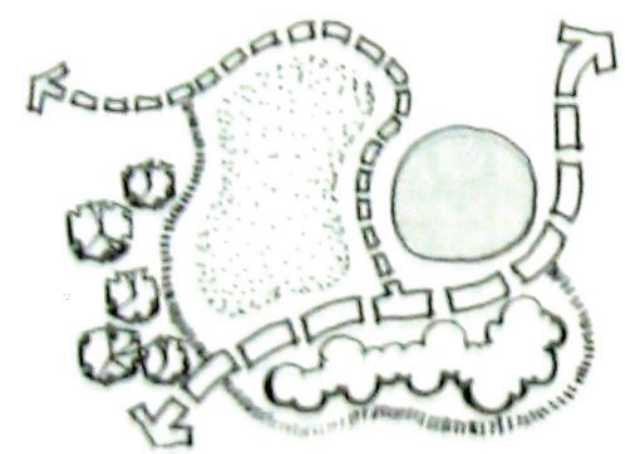

Fig. 2 Defined and seperated areas for continuousness of playground's safety according to Ref. $[8]{ }^{2}$

cause and the effect relationship. So, precautions, that prevent children acts, must be taken.

\subsubsection{Defined Field}

The circulation of traffic and people must be seperated by surrounding the playground with fence or wall to provide the security around the playground. Also "fence designs should protect natural areas without compromising visual quality [9]. There must be just one or maximal two defined entrances for continuousness of playground's safety (Figs. 1 and 2).

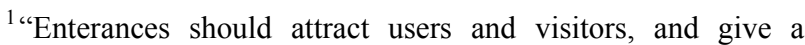
positive first impression of the setting. They should present a welcoming, "please come again" feeling to people as they leave." Moore, R. C., Goltsman, S. M., and Iacofano, D. S., 1997, p. 37.

2 "Functions, especially active and passive areas, must be separated to prevent the accidents that may happen because of mixing of the activities. While play equipments are being chosen, high play value must be thought, classification must be done according to play types, and the equipment of active, passive and creative play types must be chosen or designed firstly. The number of equipments shouldn't be decreased because of the economical concern. In that, boring places increase the risk of accident." Gür, O., and Zorlu, T., 2002, p. 273.
} 


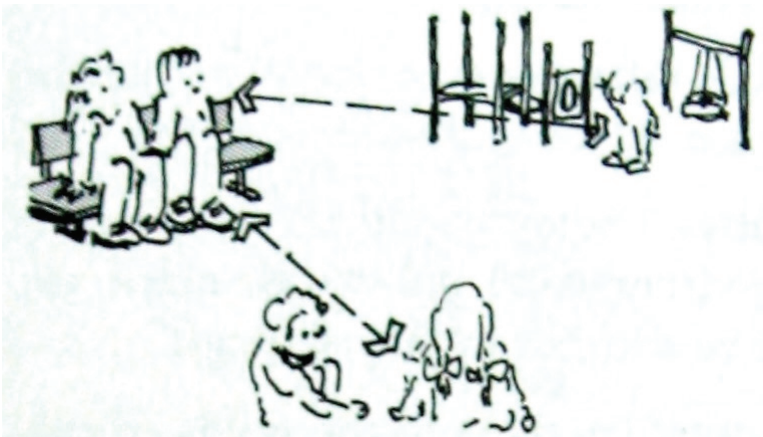

Fig. 3 Parent's point of view according to Ref. [8].

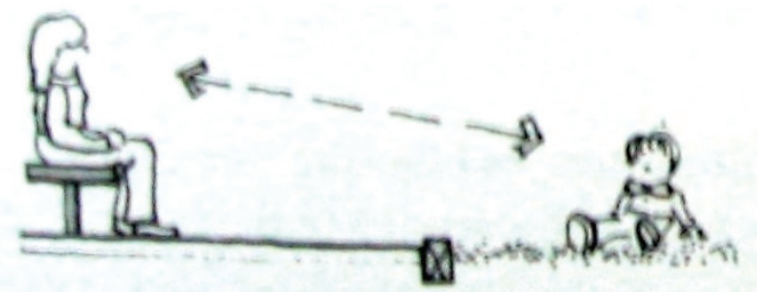

Fig. 4 Right place of sitting equipments according to Ref. [8].

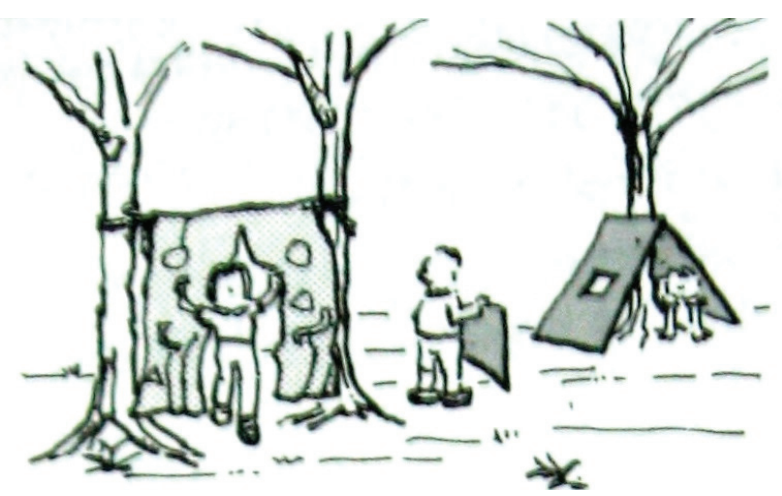

Fig. 5 Environmental supervision measures according to Ref. [8].

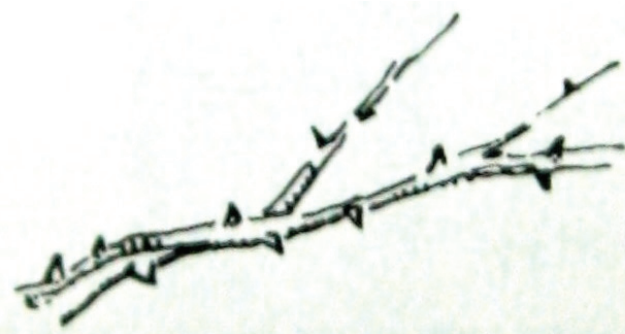

Fig. 6 Danger in playgrounds according to Ref. $[8] .^{3}$

\subsubsection{Point of View}

Beside the general security of playgrounds, "adults should have two directions of visibility into all spaces:

\footnotetext{
3"Beside this, not to cause any accident, the natural place shouldn't be left as totally natural and cleaned from facts like briars and poison plants." Moore, R. C., Goltsman, S. M., and Iacofano, D. S., 1997, p. 81.
}

from the surrounding area and from the play area itself" [8]. Especially, children under the age of 12 are very active and curious. Accordingly, they have difficulty in guessing which act is wrong and what would be the result is. Because of this, during children's activity there shouldn't be any barrier that limits parent's point of view. For this, sitting equipments must be placed near the playgrounds and on high level (Figs. 3 and 4).

\subsubsection{Environmental Supervisions}

For playground's safety (Figs. 5 and 6), "measures may also include a single entrance overlooked by an administrative office, an audio signal of each coming and going, an electronically controlled gate and a closed-circuit television" [5].

\subsection{Social Interaction}

Social interaction is basic to playing and learning. Well-designed seating and gathering areas provide settings in which children can broaden and strengthen their social relationships with each other and with the adults around them. On educational sites, small and comfortable gathering places are required where students and teachers can meet and work together. Forms include benches, decks, patios, verandas, gazebos and siting circles [9].

\subsection{Acceptable Risk}

Children use play to test their limits and deal with challenging situations [10]. Because of this, acceptable risks, that affect children's personal and physical development positively, must be allowed in playground designs. Besides, playground must be far from activities that may affect children seriously in a bad way. "Good risks and hazards are acceptable and hold few surprises. Bad risks offer no obvious developmental or other benefits [10]."'

\subsection{The Diversity of Equipment}

The method that may be applied for children to examine themselves realize their own talents, 
experience different excitements is keeping high the diversity and amount of equipment in playgrounds. Equiped insafficiently playgrounds are risky because, children look for different excitements and do inconvenient activities. "The presence of different textured equipments in designed playground provides learning by discovering and makes the play more entertaining" [11]. And also different kinds of equipments provide play opportunity for children of all abilities.

\subsection{Care and Repair}

A good standard of maintenance is essential for the long-term of play spaces. The maintenance options and costs should be analysed at the start of a project to ensure that design of the new play space is tailored accordingly. This includes everything from litter-picking to checking for hazards and replacing the features [12].

\subsection{Health and Hygiene}

Environmental contaminants are a special problem around children and people with environmental illnesses. Diagnosis and treatment are difficult because individual responses vary. Symptoms for the same exposure often range from flu-like, to allergy-like, to behavioral reactions [8]. Playgrounds must be keeped hygienic by cleaning the place from these kind of factors, and it must be controlled that attendants do their duty or not to keep the place clean. Besides, precautions must be taken for playgrounds that are prone to vandalism. "Many trees and shrubs will regrow if they are accidentally or deliberately broken, though this will depend on the extent of the damage. Where vegetation has been broken from trees, the damaged joint should be checked and cleaned off to prevent the tree from becoming infected and to ensure it heals" [12].

\subsection{Flexibility}

For an equipment, having more than one function prevents the requirement of using more materials for additional design and also eliminates uniformity in the environment by enabling different uses. Fences are the suitable examples for this situation. "To seek psychological and social comfort, children often prefer to gather around the edges of a space. The location of edges should be considered carefully in relation to other determinants, such as orientation, activity pattern, access points, etc. Where appropriate, build social/play elements into edges-design walls as places to sit, hide behind, climb on, walk along, etc. [8]." Besides, natural landforms and people-made changes in level add an interest to a site and stimulate a variety of play activities, such as rolling, crowling, sliding, balancing and jumping - activities that stimulate the vestibular sense. Topographic variety encourages fantasy play, orientation skills and hide-and-seek games. All children enjoy getting up high and looking out over the surroundings. Low mounds can be made accessible to all children [9].

\subsection{Natural Environment}

The importance of sensory stimulation and the primary experience of nature offer landscape designers the potential for creating new types of nature-based, protected havens for children, where the role of professional staff is to act as therapist/play leader [5]. In natural place (Figs. 7 and 8), children can play, enjoy and also improve their creativity with simple, perceivable, portable and natural equipments. Besides, this activity enable many group acitivities, so children find socializing opportunity. And also, "this activity in natural place provide the opportunity of being closely acquainted with nature, not just by seeing in books, by also feeling with sense organs and so learning better and discovering new things cantrary to urbanization's depressing weather. Accordingly, children learn by doing, become "participant" instead of "user", living in quality life and playing areas become the part of education" [3]. 


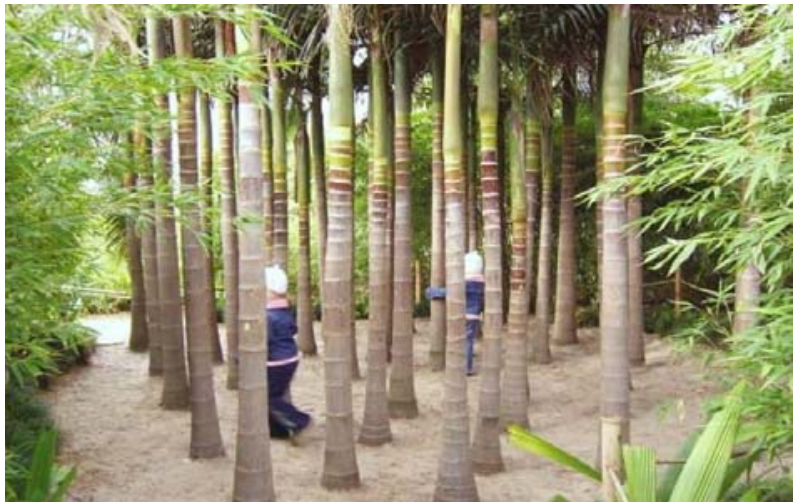

Fig. 7 A kind of natural environment [6].

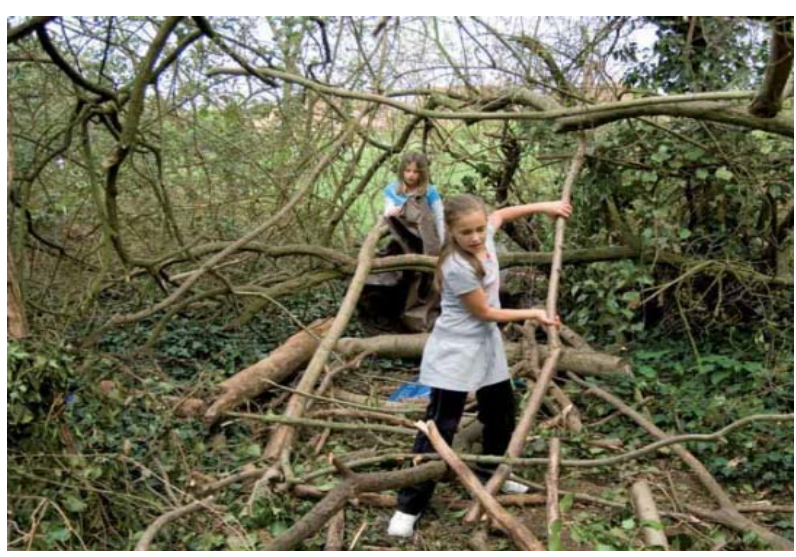

Fig. 8 A different kind of natural environment [13].

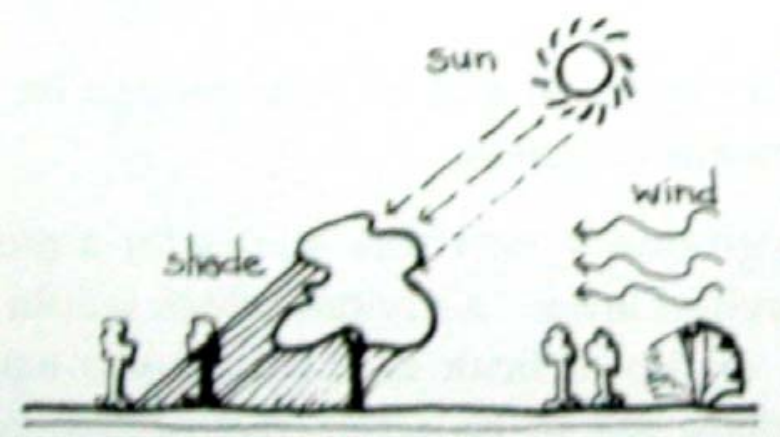

Fig. 9 Shading effects [8].

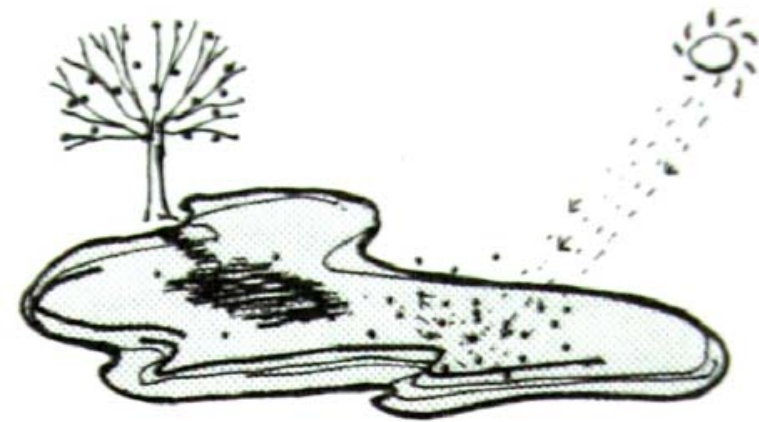

Fig. 10 Near-water condition [8].

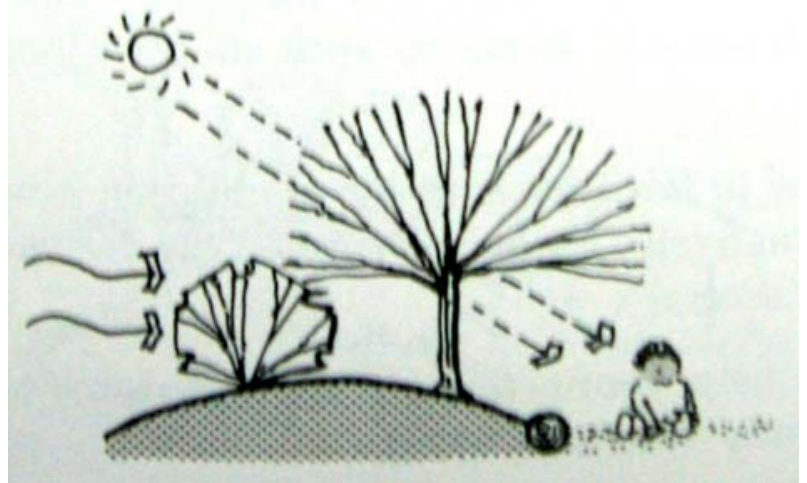

Fig. 11 Slopes effects [8].

\subsection{Climatization}

"Local climatic conditions should be taken into account when designing play areas. Best local climates for play area sites are usually on south or southeast slopes, near water and on upper or middle slopes rather than at their foot or crest. Depending on climatic conditions, play areas and activities should be located to either avoid or take advantage of the shading effects of buildings and evergreen tree clusters" [8].

Water is used to soften the air and give the feeling of coolness in piping hot days. Also, the sound of water block the noise in the environment, so it has relaxing feature (Figs. 9-11).

\subsection{Informativeness}

Informativeness is another parameter that playgrounds should have. For example, blocks that are located between trees encourage the children for creative process. Children use their structures in a realistic and imaginative manner. When children explore their ideas structurally, they observe physical principles, like form, size, weight, shape and fit. In the process of using blocks to build structures, children deal with the spatial and structural problems of balance and enclosure. Block play enables children to learn how to work and cooperate with their peers and achieve the following learning objectives [4]. And also, "children would enjoy the play for a long time by using water as a game tool. Besides, children 
would learn some pysical rules unawares while playing with water. They would see that materials have different states and liquid has different acts. Children, who make tower by using water and sand, would learn the balance and carrying capacity" [14].

Vegetation stimulates exploration and discovery, fantasy and imagination and provides an ideal setting for dramatic play, hide-and-seek games and orienteering activities. So, vegetation is the ultimate interactive playing and learning environment, and it is virtually cost-free once established [9]. In addition to these, planting can be used to create a play space that changes with the seasons and that is appealing to people of all ages [15].

\subsection{Universal Design}

According to universal design parameters, fair facilities must be provided for both disabled and nondisabled but in different features, like height and weight (Figs. 12-15). Design must be begin with the thought of "children with different abilities should be able to play together in well-designed play spaces" [15]. So, in playgrounds, there must be equipments for disabled children, too.

Firstly, the route of circulation and the enterance of activity fields must be designed wider and even for

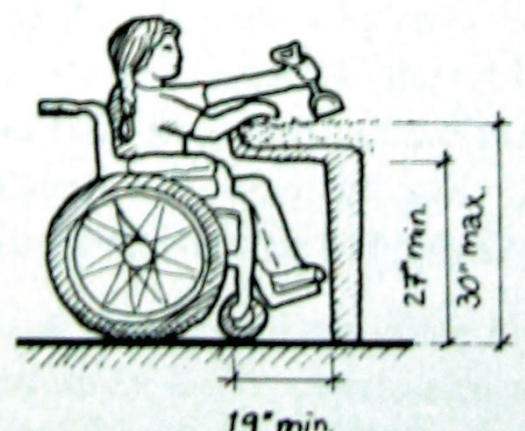

Fig. 12 Universal design for children using wheelchairs $[8]{ }^{4}$

\footnotetext{
4 “Accessible sand and water tables or trays can provide valuable play experiences for children using wheelchairs or other assistive devices. So, there should be suitable equipments for children of all features." Moore, R. C., Goltsman, S. M., and Iacofano, D. S., 1997, p. 80
}

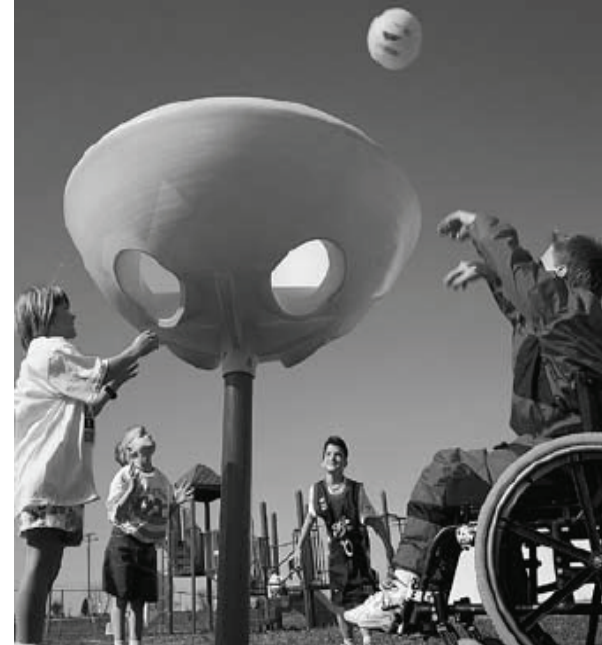

Fig. 13 Universal design for different abilities [17].

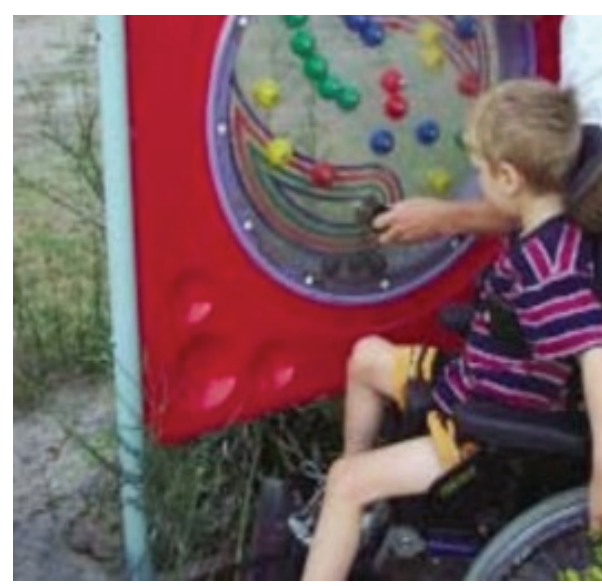

Fig. 14 Colours and light effects [6].

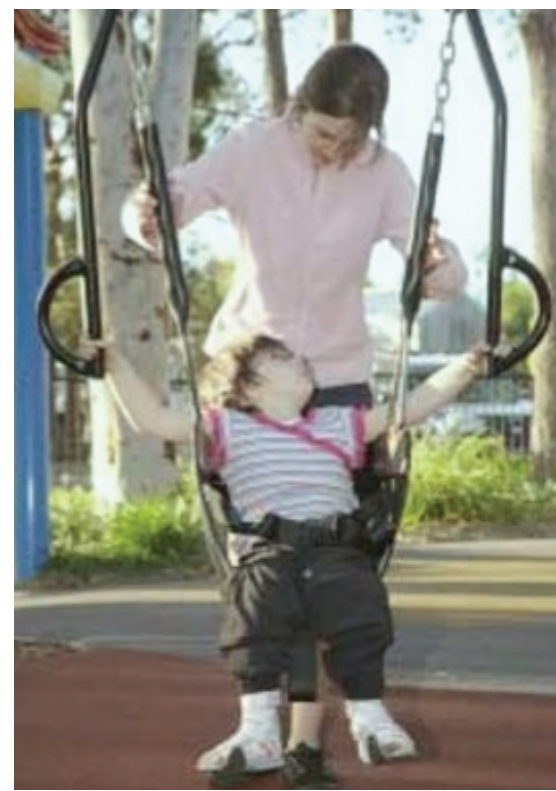

Fig. 15 Play equipments for disabled children [6].

wheel chair users. Besides, "circulation routes should 
not overlap with activity settings that can be easily disrupted by noise and movement" [8]. The routes of pedestrian must be provided directly from enterance and the main alley to important areas, like activity center, toilets, drinkable fountains, phone booths and meeting areas. Also, these route of accessibility must be designed as just ramps if there is inclined surface for the use of all people.

Sound can provide landmarks for children with visual and physical disabilities. Street lights, for example, can be coordinated with a pattern of sounds to allow the child to use an auditory cue for safe passage across the street [8].

"If it is thought that some partially-sighted people can perceive the colours by light affect" [2], it can be said that using severalizing colours in walking trails, deflections, enterances, begining and ending of the places and equipments would annihilate the blocks. And also, "to block the visual confusion, mandatory stable equipments in the place must be located closely to each other, and there shouldn't be unnecessary equipments and objects, being defined and clear must be provided in learning environment. Being contrasts between objects and the surfaces, that they are located, is important to distinguish for sight-disabled people" [16].

\section{Result and Suggestion of Guide}

According to the literature review, the parameters of quality design have been determined as collaboration, location, security, social interaction, acceptable risk, the diversity of equipment, care and repair, health and hygiene, flexibility, natural environment, climatization, informativeness and universal design. In line with this classification, the guide as follows has been suggested. The parameters of quality design must be considered in related steps.

\subsection{Step: Deciding the Project}

The city must be analysed according to distribution of population, age and needs.
The suitable location for the project must be chosen with the collaboration of local administrations and public by arranging meetings and making surveys.

The factors, like harmony to the environment, intensity of traffic or air pollution, must be considered for the location.

\subsection{Step: Designing the Project}

Especially, children's opinion must be taken and, if a clear answer could not be received, their attitudes must be observed.

Security parameters, like defined place, number of entrances, warnings, point of view or risk factors, should be considered.

Every kind of equipments in playground should be designed for people of all number or feature.

The playground should be inviting.

Equipments, unlike traditional play equipments, should vary that contains different experiences and activities by considering of risk levels.

The playground and the equipments should have flexible use feature to support diversity of activities and prevent using more material.

The activities at the playground should be educational and enable to discover creativity of children.

Playgrounds should be supported with green fields, children should be intertwined with the nature. Besides, climatization elements should be used which support the nature.

The areas should be designed separately according to vary of activities and the user's ages.

There should be enough rubbishbin, benches and lighting equipments for night use, toilet and drinkable fountain at the playground.

There should be semi-closed or closed places to take shelter, and superstructure elements should be located at suitable places to prevent more sunlight and bad air conditions.

Playgrounds must be purged from artificial materials, and natural, esthetic solutions should be found. 
Table 1 Design parameters and contents.

\begin{tabular}{|c|c|}
\hline Design parameter & Content of parameters \\
\hline Collaboration & $\begin{array}{l}\text { Children } \\
\text { Families } \\
\text { Specialist } \\
\text { Government }\end{array}$ \\
\hline Location & $\begin{array}{l}\text { Central place } \\
\text { Traffic } \\
\text { Air polution } \\
\text { Noise }\end{array}$ \\
\hline Security & $\begin{array}{l}\text { Defined field (fence, enterance and seperated activities) } \\
\text { Point of view } \\
\text { Environmental supervisions (cleaning and security units) }\end{array}$ \\
\hline Social interaction & $\begin{array}{l}\text { Gathering places } \\
\text { Different kinds of activities }\end{array}$ \\
\hline Acceptable risk & Safe equipments \\
\hline The diversity of equipment & $\begin{array}{l}\text { Suitability to all kinds of children } \\
\text { Optimum numbered equipments }\end{array}$ \\
\hline Care and repair & Checking periodically \\
\hline Health and hygiene & $\begin{array}{l}\text { Cleaning periodically } \\
\text { Preventing vandalism }\end{array}$ \\
\hline Flexibility & Varity of play activities \\
\hline Natural environment & $\begin{array}{l}\text { Flexibility } \\
\text { Informativeness } \\
\text { Socialization } \\
\end{array}$ \\
\hline Climatization & $\begin{array}{l}\text { Water, trees } \\
\text { Analyzing climatic data } \\
\text { Semi-open spaces }\end{array}$ \\
\hline Informativeness & $\begin{array}{l}\text { Creative play } \\
\text { Flexible elements, like vegetation, water and sand }\end{array}$ \\
\hline Universal design & $\begin{array}{l}\text { Designing for every kind of people } \\
\text { Equal use for everyone }\end{array}$ \\
\hline
\end{tabular}

Playgrounds and equipments which addapted, universal design principles should appeal to all kind of people.

\subsection{Step: Implementation of the Project}

During the project implementation process, participation of public and presenting their opinion must be allowed, while the area must be controlled regularly.

\subsection{Step: Testing the Project}

Municipality must maintain the care of the playground periodically, and the place must be kept hygienic.

During the using of project, the area must be controlled and observed, and opinion of public must be taken periodically.

\subsection{Step: Taking Precaution}

If there is a problem in the using process, this problem must be solved and precautions must be taken not to experince it during the other projects again.

Table 1 shows the parameters of playground design and contents of parameters processionally.

\section{Conclusions}

Within this study and suggested guide, it is expected that designers and management would take this guide into consideration and design the playgrounds according to the suggestions. So, playgrounds would be preferred places again and these places would provide not only entertainment but also learning. Children would find the opportunity of 
improve themselves and playgrounds would be the important areas for childhood which is the important stage of humanity.

\section{References}

[1] Çukur, D. 2009. "The Importance of Play and Spatial Arrangements That Increase the Value of Play around Housing (Çocuk Dinlenimi Açısından Oyunun Önemi ve Konut Yakın Çevresinde Oyun Değerini Artırıcı Mekansal Düzenlemeler)." Ege Architecture Issue. Accessed November 12, 2015. http://www.izmimod.org.tr/egemim/69/3.pdf.

[2] Gür, Ö., and Zorlu, Ş. 2002. Children Places (Çocuk Mekanlarl). İstanbul: YEM (Yap1 Endüstri Merkezi) Publications.

[3] Özdemir, A. 2010. Experience of Europe in Playgrounds Regulated with Pedagogical and Ecological Approach (Pedagojik ve Ekolojik Yaklaşım ile Düzenlenmiş Çocuk Mekanlarinda Avrupa Deneyimi). Numbered 2008-1-TR-1-LEO03-04034 LdV Project, T.C. Bartın University.

[4] Sanoff, H. 1995. "Creating Environments for Young Children." North Carolina State University Raleigh School of Design. Accessed November 12, 2015. http://files.eric.ed.gov/fulltext/ED394640.pdf.

[5] Moore, C., and Cosco, G. 2005. "Well-Being by Nature: Therapeutic Gardens for Children." American Society of Landscape Architects. Accessed November 12, 2015. http://naturalearning.org/sites/default/files/MooreCoscoT herapeuticGardenLATIS.pdf.

[6] Department for Victorian Communities. 2007. "The Good Play Space Guide: 'I Can Play Too'.” Department for Victorian Communities. Accessed November 12, 2015. http://www.fairplayforchildren.org/pdf/12245394 81.pdf.

[7] International Save the Children Alliance. 2008. "Child Friendly Spaces in Emergencies: A Handbook for Save the Children Staff." International Save the Children Alliance. Accessed November 12, 2015. http://www.unicef.org/french/videoaudio/PDFs/Guideline s_on_Child_Friendly_Spaces_-_SAVE.pdf.

[8] Moore, C., Goltsman, S., and Iacofano, S. D. 1997. Play for All Guidelines, Planning, Design and Management of Outdoor Play Settings for All Children. Berkeley: MIG Comunications.
[9] Moore, R. C. 1996. "Outdoor Settings for Playing and Learning: Designing School Grounds to Meet the Needs of the Whole Child and Whole Curriculum." The NAMTA Journal 21 (3): 97-120. Accessed November 12, 2015. https://naturalearning.org/sites/default/files/OutdoorSettin gsForPlaying.pdf.

[10] Ball, D., Gill, T., and Spiegal, B. 2012. "Managing Risk in Play Provision: Implementation Guide." Presented at National Children's Bureau, Play Safety Forum. Accessed November 12, 2015. http://www.playengland.o rg.uk/media/172644/managing-risk-in-play-provision.pdf.

[11] Kuşuluoğlu, D. 2013. "Qualitative and Quantitative Evaluation of Children Play Spaces in İstanbul Kadıköy (İstanbul Kadıköy İlçesindeki Çocuk Oyun Alanlarının Nitel ve Nicel Açıdan Değerlendirilmesi).” Master thesis, İstanbul Technical University.

[12] Davis, L., White, A., and Knight, J. 2015. "Nature Play: Maintenance Guide.” Play England. Accessed November 12, 2015. http://www.playengland.org.uk/media/120468/ nature-play-maintenance-guide.pdf.

[13] Lester, S., and Maudsley, M. 2007. "Play Naturally, A Review of Children's Natural Play, Making Space for Play." Play England. Accessed November 12, 2015. http://www.playengland.org.uk/.

[14] Turgut, H., and Yılmaz, S. 2010. "Creating Ecological Based Children Play Spaces (Ekolojik Temelli Çocuk Oyun Alanlarının Oluşturulması).” Presented at 3rd National Blacksea Silviculture Congress, Artvin, Turkey.

[15] Shackell, A., Butler, N., Doyle, P., and Ball, D. 2008. "Design for Play: A Guide to Creating Successful Play Spaces." Free Play Network. Accessed November 12, 2015. http://www.playengland.org.uk/media/141887/desi gn-for-play-introduction.pdf.

[16] Potur, A. 2014. "The Eyes of the Skin: Learning Environments and Very Sensible Spatial Experiences According to Visually Impaired Individuals (Tenin Gözleri: Görme Engellilere Yönelik Öğrenme Ortamları ve Çok Duyulu Mekansal Deneyimler)." Ege Architecture Issue. Accessed November 12, 2015. http://www.egemimarlik.org/85-86/7.pdf.

[17] U.S. Access Board. 2005. "Accessible Play Areas: A Summary of Accessibility Guidelines for Play Areas." U.S. Access Board. Accessed November 12, 2015. https://www.access-board.gov/attachments/article/1369/ play-guide.pdf. 